\title{
The UK's Changing Party System: the Prospects for a Party Realignment at Westminster
}

David Sanders

Party systems - and support for the parties that comprise them - develop and evolve in response to three broad sets of factors: electoral rules; the actions and decisions of political elites; and the political beliefs, attitudes and preferences of mass publics. The evolution of the UK's party system since 1945 reflects the tension between the strong constraining impact of electoral rules and deep-seated, long-term changes in public opinion. Declining party identification and increasing popular disillusion with Labour and the Conservatives have weakened what, for the two main governing parties, were the 'virtuous circle' effects of FirstPast-the-Post elections. These long-term changes have stimulated movement towards a multi-party system - although, as UKIP's experience in the 2015 general election showed, FPTP can still reassert its virtuous (or in this case, vicious) circle effects. This paper reviews the factors that have underpinned the UK's changing party systems over the last six decades. It argues that, partly as a result of recent decisions by Labour and Conservative elites, UK public opinion is now ripe for a party system realignment. With the Conservatives divided over Europe and human rights, and Labour divided over immigration and whether the party should be primarily a party of government or a protest movement, an important opportunity has opened up for a resurgence of the liberal political centre. The key issue is whether or not sufficient politicians from the centrist factions of Labour and the Conservatives possess the will and courage to develop it.

Part 1 of this paper reviews the conventional wisdom about the relationship between electoral rules and patterns of party competition. Duverger's Law (Duverger, 1954) has undoubtedly acted as a constraint on the development of parties that could challenge the post-war dominance of Labour and the Conservatives. However, it is also the case that the UK's party system (or more correctly, party systems if we consider local government and the devolved assemblies in Scotland, Northern Ireland and Wales as well as the Westminster parliament) has become increasingly fragmented since 1945. Part 2 briefly documents this increasing fragmentation. It outlines the decline of the Westminster two-party vote since the 1950s; the increasing number of local councils where no single party has overall control, especially after 2000; and the clear multi-party systems (encouraged by electoral rules that include a proportional component in terms of regional lists) that have characterised each of the UK's devolved assemblies since 1998. The section also examines the increasing disproportionality between parties' vote shares and seat shares in the Westminster parliament, a phenomenon that has grown as the vote shares of the two major parties have declined.

Part 3 examines the main factors that have contributed to the increasing party fragmentation at Westminster. It differentiates between explanatory factors that are capable of being measured systematically, in terms of both their extent and their impact on fragmentation, and those that are not. Among the 'unmeasurable factors'are the long-term decline in deference 
towards received wisdom and elite judgment; the rise of new regional, ethnic and religious identities; increased media criticism (including social media criticism) of conventional politics and politicians; and the unintended consequences of elite decisions. Key among the measurable factors are the long-term decline in party identification and the gradual weakening of class-based voting. The final section considers the prospects for a new realignment of the Westminster party system. It analyses recently collected survey data which show that Authoritarian Populist attitudes are widespread among the UK mass public. Cluster analysis suggests that there are now four distinct 'political tribes' among UK voters, defined in terms of their left-right positions and their attitudes towards Europe, immigration, human rights and Britain's foreign policy role in the world. A new centre party could make a strong electoral appeal to a large proportion of two of these tribes, acting as a bulwark against the otherwise likely election of future authoritarian populist governments at Westminster.

\section{First-Past-the-Post (FPTP) versus increasing party fragmentation, 1945-2016}

The UK has always had a rather more complex party structure than the simple two- or twoand-a-half party system typically used by comparative political analysts to characterise the Westminster parliament. Many towns and cities in Great Britain have evolved local party systems, particularly since 1945, which look very different from the classic Conservative/Labour/Liberal (Democrat) Westminster model. Northern Ireland has had its own distinctive system, variously instituted, since the 1920s. And since devolution in the late 1990s, Scotland and Wales have developed entirely new systems that have in turn evolved in different ways over time. This said, Duverger's conclusions about the impact of FPTP or plurality electoral rules on party competition have proved a useful way of explaining why the Conservatives and Labour have maintained their electoral dominance for most of the postwar period - and of explaining why third parties without a clear regional base have found it extraordinarily difficult to make an electoral breakthrough.

The core of Duverger's analysis is very straightforward: plurality voting, over time, encourages competition between two broad-based, catch-all parties, making it difficult for third parties to challenge the two-party status quo. On occasion, of course, a minor party might be able to sustain itself under FPTP (especially if could make some sort of local or regional appeal) or one of the two parties might even (temporarily) achieve the status of a 'dominant party'. However, for the two major parties under FPTP, a 'virtuous circle' calculus of voting and activism tends to operate - which for any challenger party, by implication, acts as a vicious circle. Voters and political activists learn, either in advance or through experience, that third party votes and activism tend to be wasted in terms of gaining parliamentary seats. Both voters and would-be activists accordingly gravitate towards one or other of the two major parties, even if this involves voting tactically for a lesser evil or, for the activist, 'compromising' with the dominant values of the party s/he has decided to join. This gravitation effect in turn squeezes the third party vote, which encourages the sense after an election that third party voting and activism have been wasteful - thus reinforcing the FPTP virtuous/vicious circle. The counterpoint to plurality voting rules, of course, is Proportional Representation (PR) in its various forms. In Duverger's view, PR encourages 
multi-party competition, since under PR there are fewer (if any) wasted votes or wasted activism. This enables 'sincere' voting (that is, genuine first preference voting) to predominate and ensures that the public's preferences - however fragmented they might be can be reasonably accurately translated into parliamentary seats. For Duverger, it is no accident (as subsequent studies have repeatedly shown) that plurality systems exhibit the highest disparities between parties' vote shares and parliamentary seat shares and that these disparities are associated (other things being equal) with higher levels of dissatisfaction with democracy.

Plurality electoral rules, of course, do not mean there is no serious challenge to existing parties. Irish nationalists made a successful challenge to the dominant Conservative and Liberal parties in the first two decades of the twentieth century, resulting in Irish independence in 1922. And Labour successfully supplanted the Liberal Party in the decade or so after the First World War. The logic of the FPTP virtuous circle soon reasserted itself, however. The Liberals received only seven percent of the popular vote in the 1931 general election - a position from which they did not really start to recover until 1974. Yet it is clear that over the last 40 years or so, the Conservative/Labour two-party system at Westminster has transmuted into a form of 'unbalanced multi-partism' - involving the Conservatives, Labour, Liberal Democrats, SNP and Plaid Cymru - even though the electoral rules have not changed. Electoral rules do not determine party competition, though they do constrain it in different ways. Regionally-focused or national parties can clearly prosper under FPTP but those parties which lack either a clear regional/national base (like the SNP and PC and to a lesser extent the Liberals) or a class demographic (like the Conservatives and Labour, at least in the past) find that their support, even if it is considerable, can be spread so thinly as to deliver no real electoral payoff. UKIP's experience in the 2015 general election, with twelve percent of the popular vote and only one parliamentary seat to show for it, is a clear testimony to the dangers of 'no distinctive demographic'. All this said, the experiences of the devolved assemblies in Scotland, Wales and Northern Ireland clearly support the Duverger thesis that the introduction of a substantial PR component in the electoral process strongly encourages multi-partism: since their inception, all the newly devolved assemblies (as demonstrated in the next section) have been characterised by multi-party competition.

\section{The fragmentation of Westminster, Devolved Assembly and Local Council voting in historical perspective}

The time-scales over which changes in party competition can usefully be analysed vary according to the different levels of governance. For Westminster elections, the earliest reference point is generally considered to be 1832, when the UK's modern party system, focusing on competition between Conservatives and Liberals, was initiated. For the devolved assemblies, the simplest start date is the first set of post-devolution elections - 1998 in Northern Ireland and 1999 in Scotland and Wales. For local elections, the position is complicated by the significant changes in local authority boundaries and designations that have been introduced, particularly since 1945. The most consistent basis for an over-time comparison is to consider the electoral position in the UK's major cities (excluding London, 
which has had a variety of distinctive arrangements) since 1945. The discussion here focuses initially on the vote shares obtained by the various parties, turning then to discuss the relationship between vote shares and seat shares in the national, Westminster context.

Westminster. Figure 1 reports the changes in party vote shares for the Westminster parliament between 1832 and 2015. Until 1910, support for the Conservatives and Liberals was overwhelming, with very low levels of support for other parties. From 1918 to 1931 there was a period of transition in which Labour replaced the Liberals as one of the two 'major' parties able to benefit from the FPTP virtuous circle. From the mid1950s, there was a gradual decline in the combined Labour and Conservative share of the vote, with a concomitant rise in support for the Liberals (Liberal-Democrats) and 'Other'. ${ }^{1}$ By 2015, the constraining effects of FPTP had loosened sufficiently for roughly a third of the electorate to decide to vote for parties other than Labour and the Conservatives. Support for UKIP (at 12.5 percent) was part of the explanation for the loosening. However, as Figure 2 shows, another part of the story was the success of nationalist parties in Wales and Scotland. Plaid Cymru and the Scottish National Party started to attract very small percentages of Welsh and Scottish votes respectively in Westminster elections in 1931 - but by 2015 this had grown to a 12 percent share for PC in Wales and a massive 50 percent SNP share in the wake of the 2014 Scottish independence referendum.

Devolved Assemblies. Figures 3-5 show the changing vote share patterns for the three UK devolved assemblies after 1998. In all three cases, given that roughly half the seats were awarded on the basis of parties' vote shares for regional lists, votes were from the outset relatively evenly distributed across four or more parties. The devolved assemblies, in short, have consistently been characterised by multi-party systems. In Scotland in 1999, as Figure 3 shows, Labour, the SNP, the Conservatives, Liberal-Democrats and even 'Others' secured substantial shares of the vote. This pattern continued through 2003 and 2007, though by 2011, the SNP had achieved a clear dominance, which was reinforced even more strongly in 2016. An analogous position is described in Figure 4, which presents equivalent data for Wales. In 1999, four parties obtained substantial votes shares, though Labour and Plaid Cymru were in a sufficiently strong position to suggest that a two-party system could develop. In fact, by 2003, PC had lost support to such an extent that Labour was clearly the dominant party, a position that it broadly maintained through to 2016. The growth of UKIP, however, meant that by 2016 votes for the Welsh Assembly were distributed across five parties - each with Assembly representation. Finally, Figure 5 summarises the position in Northern Ireland Assembly elections since 1998. From the beginning, voting for the NI Assembly followed a very clear multi-party vote pattern, with votes distributed across five parties plus 'others'. By 2007, this had transmuted into a system in which, though still involving substantial voting for multiple parties, the Democratic Unionists and Sinn Fein had established themselves as the two dominant parties - though on only one occasion (the DUP in 2011) did either of them secure over 30 percent of the popular (list) vote.

Local Councils. As an illustration of the changing levels of fragmentation in UK local authority voting, Figure 6 reports the year-by-year variations in the number of major UK city councils (out of a total of 22 councils whose boundaries and status remained broadly stable 
over the 1945-2016 period) in which there was No Overall Control (NOC) by a single party or formal coalition of parties. The NOC characterisation is obviously an imperfect measure of voting fragmentation, but it does give a general indication of the extent to which the Conservative and Labour parties fail to perform effectively in local elections: a higher incidence of NOC, in short, reflects a higher level of local vote fragmentation. Viewed in this light, Figure 6 shows that NOC is by no means a new phenomenon. Its incidence grew slowly in the 1970s and 1980s and increased markedly after 2000, with half of the 22 councils in the sample group experiencing NOC in 2006. As with Westminster voting, a constant set of electoral rules based on FPTP, is capable of producing some degree of voting fragmentation, notwithstanding Duverger's Law.

Vote shares, seat shares and disproportionality. The evidence reported in Figures 1-6 shows that voting fragmentation has been a feature of UK representative democracy to varying degrees both over time and at the three levels reviewed. Party systems, however, are defined not just by voting patterns in any one series of elections, but also by the distribution of seats that result from the way votes are cast. As noted earlier, FPTP is less likely than electoral rules based on some form of Proportional Representation accurately to translate vote shares into seat shares. Typically, FPTP gives the winning party a parliamentary majority to govern only at the cost of depriving 'minor' parties of a 'fair' share of parliamentary seats. Analysts have devised a number of different measures of vote share/seat share disproportionality. Most measures focus on the idea of the Effective Number of Parties. ${ }^{2}$ For any given parliament, this Effective Number can be calculated for the distributions of both vote shares and seat shares: the gap between the two is one way of summarising any vote/seat disproportionality. ${ }^{3}$ Figure 7 shows the gap between the Effective Number of Parties (ENP) in terms of votes and seats at Westminster since 1900. Since 1918, the ENP in terms of votes has been higher than the ENP in terms of seats. The gap narrowed briefly in the early 1950s, but since then it has been growing progressively so that by 2015 electors votes were spread across 3.9 Effective Parties whereas Commons seats were distributed to 2.5 Effective Parties. This considerable gap to a large extent reflects the way in which the FPTP virtuous circle still benefits Labour and the Conservatives as the two 'major' competing parties, even though the electorate has increasingly and repeatedly signalled its overall collective preference for a multi-party system.

It is well beyond the scope of this paper to analyse the extent to which UK local authority elections have historically produced a gap between ENP-votes and ENP-seats: this would involve a massive exercise in data collection and analysis that might well reveal nothing particularly interesting beyond an obvious parallel with what has been happening at Westminster since 1918. However, as far as the devolved assemblies are concerned, a similar set of calculations to those reported in Figure 7 can be undertaken for the relatively short period since 1998. Table 1 summarises the results of these calculations. The ENP-votes scores are all higher than in the Westminster parliament - as would be expected given that half the seats in the devolved assemblies are allocated by PR. However, as Table 1 shows, in all three contexts the ENP-seats scores are lower than their equivalent ENP-votes scores, implying that there is a degree of disproportionality even in the three devolved assemblies. In 
short, even in these assemblies the continuing FPTP component of the electoral rules constrains the representation of more peripheral parties, thereby reducing the degree of multipartism that would be expected purely on the basis of way people cast their votes.

The broad conclusions suggested by the foregoing discussion are straightforward.

Notwithstanding Britain's tradition of First-Past-the-Post elections, the UK has been moving slowly towards a more fragmented, multi-party system since the 1950s. The process of fragmentation has been gradual and punctuated by brief periods of above-trend advance, but it has been inexorable. Voters have gradually been deserting the two major parties, even though the constraints of FPTP and its associated disproportionate translation of votes into seats have inhibited third-party (and fourth and fifth party) success. The explicit provision for regional list votes as a complement to FPTP in the devolved assemblies in Scotland, Wales and Northern Ireland has reduced (though not eliminated) disproportionality in these assemblies. Moreover, in Scotland and Wales, national assembly voting (as with European Parliament voting, which was based on PR regional lists from 1993) has almost certainly affected subsequent voting in Westminster elections. It has broken old habits and allowed some voters to support parties they previously considered marginal: Labour was almost a certainly a victim of this tendency in Scotland in the 2015 general election. Devolution, in short, has probably accelerated the movement towards multi-partism in the Westminster parliament - even though FPTP still acts as a source of disproportionality by constraining the Effective Number of Parties in terms of seats.

\section{What explains the increasing fragmentation of the UK party system and the decline of support for Labour and the Conservatives?}

It is by no means a simple matter systematically to assess the factors that have undercut the 'virtuous circle' of the post-war two-party system. This is partly because the necessary data for evaluating the various possible explanations for vote (and, to a lesser extent, seat) fragmentation are unavailable and partly because of the statistical difficulty of estimating causal effects among variables that are potentially reciprocally related. With these constraints in mind, I offer an analysis that is speculative but 'consistent with the available evidence', rather than one that rigorously tests a more limited set of precise explanatory claims.

I begin with what I described earlier as the 'unmeasurable' factors. These are 'unmeasurable' in two senses - in terms of being able (a) accurately to measure how they have changed over the period since the post-war two-party system began to fragment in the 1950s and, consequently, (b) to assess their effects on the fragmentation process itself. There are arguably five main 'unmeasurables' that have contributed to party fragmentation. The first is cultural - the decline of deference, the reduced preparedness of mass publics to defer to the wisdom, judgment and authority of elites. There has obviously always been a disposition among some sections of the public to challenge the status quo. It is nonetheless clear from World Values Surveys (WVS) conducted since 1980 that deference as a general characteristic is much less prevalent, both in the UK and elsewhere in the developed world, than it was in the immediate post-war years. The key evidence in this context relates to the levels of 
deference shown by different cohorts of WVS respondents: the younger the cohort, the lower the level of deference displayed. For example, those born after 1951 exhibit deference levels roughly half the levels shown by those born between 1921 and 1930 (Nevitte, 2011). It is difficult to demonstrate that this general decline in deference has a direct impact on popular disaffection with the main parties of government, but it seems likely that it has played some sort of indirect role in increasing people's doubts about the wisdom of the actions of successive (Labour and Conservative) governments.

A second possible 'unmeasurable' factor underpinning party fragmentation relates to the rise of 'alternative' identities. Gilbert and Sullivan's Private Willis from Iolanthe is often quoted to exemplify the late nineteenth century orthodoxy about the importance and ubiquity of party identity:

How Nature always does contrive...

That every boy and every gal

That's born into the world alive

Is either a little Liberal

Or else a little Conservative!

By the late 1930s, of course, Labour had substituted for the Liberals in popular affections. However, as demonstrated below, party identifications have declined significantly since the early 1960s. They have been variously supplemented and replaced by a proliferation of new political and quasi-political identities - by Scottish and Welsh identities in those two countries, by ethnic and religious identities among the UK's growing ethnic minority population (Heath et al, 2013), and even for some by European identity (Isernia et al, 2012). The difficulty with trying to assess the changing importance of these 'new' identities is that there are no reliable baseline data extending back in time that might enable any changes in identity patterns to be measured and assessed. This means that although we know that these identities are important (especially national identities in Scotland and Wales) in determining party choices now, it is not possible assess how far they have driven out old party identities and therefore contributed to party fragmentation.

A third 'unmeasurable' source of fragmentation is the increased level of traditional media criticism of politicians, which has in turn increased popular disillusion with professional politicians and established parties. It is easy to assert this proposition but far more difficult to demonstrate it. Nonetheless, we are all familiar with the more confrontational style of political interviewing on radio and television that has developed in the UK over the last three decades or so. And the Daily Telegraph and other newspapers have seemed to regard it almost as a duty in recent years to expose the peccadillos and errors of judgment made by politicians of all parties at every opportunity - a development that for many observers has contributed to the increasing lack of trust that voters have in politics and politicians (see for example, Whiteley et al, 2013). Although it is very difficult to establish empirically either the extent to which these changes have occurred and whether or not they have affected fragmentation, it would be unwise to conclude that they have had no effect. 
A similar conclusion is suggested with regard to a fourth possible source of party fragmentation: the rise and rise of social media conversations and exchanges. Analysts are only starting to get a proper handle on how to measure and assess these exchanges but it seems clear from anecdotal evidence that most of them involve participants listening and talking to people largely like themselves. The low transactions costs of social media interactions mean that it is relatively easy to form ever-smaller, more specialised political groupings in which the like-minded converse. This clearly makes it easier for 'groupthink' mechanisms to operate and for participants to reinforce each other in their views and to convince themselves that those views (since they are rarely contradicted) are widely shared. Again, it is difficult to assess either the extent of such social media conversations or to show that they connected to party fragmentation - but it seems likely that they have helped to reinforce the fragmentation process in the relatively recent past and that they will continue to be of relevance in the future.

The final 'unmeasurable' factor underpinning fragmentation concerns the unintended consequences of elite decisions. It is all but impossible to demonstrate the connections between specific decisions and such a generalised long-term process as party fragmentation. In my view, however, there are three identifiable decisions that have had - and will continue to have - profound consequences for the unity and character of the Labour and Conservative parties. The first was the Blair government's decision to establish the Scottish parliament from 1999. Blair's aim in devolving power was to preserve the union between Scotland and the rest of the UK by making modest concessions to Scottish demands for increased decisionmaking autonomy. At the same time, Blair introduced part-PR electoral arrangements that would minimise the chances of an SNP-led Scottish government (since all the other parties were pro-union), thereby making it difficult for the SNP to build further momentum for its core cause of independence. In the event, of course, Blair's plans rapidly went awry. In May 2007, the first SNP minority administration took office in Holyrood. It was so successful that it was elected with a majority in 2011. The knock-on consequence of the SNP's domestic success, even in the wake of an unsuccessful referendum in 2014, was that the party annihilated Labour in Scotland in the 2015 Westminster elections. To the delight of all lovers of irony, Labour's Scotland strategy had had the very opposite effect of what was intended and party fragmentation at Westminster had been reinforced.

The second elite decision that increased the tendency towards party fragmentation at Westminster was Ed Miliband's reform of Labour leader-election rules in March 2014. John Smith had introduced One Member One Vote (OMOV) in September 1993, but the voting power of party activists had been curbed by the continuing existence of an electoral college in which MPs, MEPs and trade unions were also represented. Miliband's reforms introduced genuine OMOV and these operated for the first time in July 2015, following his resignation after the 2015 election defeat. The empowerment of the grass roots activists that this implied, combined with Labour MPs decision to include Jeremy Corbyn as one of the balloted candidates for leader, produced an overwhelming victory for Corbyn as the representative of the party's radical left (a victory that was confirmed in a second ballot in October 2016). The unintended consequence of this concatenation of rule change and nomination naivety plunged 
Labour into a crisis over whether Labour should be an activist-driven campaigning party that articulates a radical voice for the dispossessed or a realistically aspirant party of government that, in office, could genuinely improve the lives of 'ordinary working people'. Corbyn's victory has given many Labour activists the voice and policies they have always wanted. But it has distanced the party from both the median voter and traditional Labour voters and left large numbers of Labour MPs wondering how on earth the party can ever recover electorally. As I will discuss in the final section, there is an opportunity here for a new centre-ground political force in the UK, if enough Labour MPs can convince themselves that the need for politicians to take practical action which improves ordinary people's lives is more important than out-dated notions of party loyalty and betrayal.

The third elite decision worth mentioning is David Cameron's decision, in the run-up to the 2015 general election, to promise an 'in/out' referendum on Britain's EU membership by 2017. Cameron clearly expected that he would be able to negotiate a deal (on improved membership terms for the UK) with the UK's EU partners that would be acceptable to the UK public, and that he would accordingly win any such referendum. His failure to understand the risks he was running or to campaign effectively for the deal he had secured resulted in his rapid political demise and his replacement by a Conservative government that seems bent on both a 'hard Brexit' and on moving the Conservatives firmly to the authoritarian right. The centre of gravity of the Conservative Party under Theresa May has shifted towards an anti-Europeanist, anti-immigrant, anti-human-rights stance that leaves the pro-EU social liberals, who formed the vanguard of the party under Cameron, very isolated. As with Labour's centrists, Tory centrists have an opportunity to defect from a party with which they no longer have very much in common. Again, this is an issue to which I return in the final section.

The factors outlined above offer an incomplete and largely anecdotal account of why party fragmentation has increased in Britain in recent decades. There are two further (measurable) factors, however, where more specific corroborating evidence can be provided. Yet even here, the corroboration is limited in the sense that these measurable factors all suffer from a potential 'endogeneity' problem (a problem, incidentally, that besets large swathes of social science research) - that is, they are all subject to the potential criticism that they are the consequence of declining support for the two main parties, rather than its cause. Given that the necessary data for resolving this sort of endogeneity problem are not available, I simply hypothesise that these two measurables do indeed underpin the fragmentation process and then examine the data to determine whether or not they are consistent with such a claim.

The decline of Party Identification. Party identification (or PID) is one of the most commonly used concepts in the explanation of voting patterns. It can be characterised in various ways but in essence constitutes an individual's long-term predisposition to support one party rather than another - though such predispositions can change over time (Clarke et al, 2004). Analyses of PID typically differentiate among Very Strong, Fairly Strong and Not Very Strong Identifiers, all of whom are distinguished from Non-identifiers. Identifying with a party is not a guarantee that an individual will support it, but Very Strong Identification with a party is a powerful indication that an individual will indeed vote for it at the next 
election. Equally, having no identification generally signifies that an individual's vote is 'up for grabs' at any given election - that vote choices will be affected more by perceptions of leadership qualities, evaluations of policy platforms, and assessments of the likely managerial competencies of the rival leadership teams.

Figure 8 shows the aggregate changes in strength of party identification between 1964 (when PID was first systematically measured in the UK) and 2015. Fairly Strong identifiers remain broadly constant at around $40 \%$ of voters. Not Very Strong identifiers - the least committed identifiers - increase from around $10 \%$ to about $23 \%$. However, Very Strong Identifiers decline from $45 \%$ of voters in 1964 to $15 \%$ in 2015 . And crucially, people with No Identification have increased from $5 \%$ of the electorate to over $20 \%$. Figure 9 presents the data in a slightly different form, showing how PID strength has fallen for the two major parties and for the Liberal Democrats since 1964. For simplicity of presentation, the strength measures are presented in index form. The two figures tell the same story, however.

Together, they show conclusively that voters have become progressively less committed to the main established political parties in the half century since 1964. It is hardly surprising in these circumstances that they have been prepared to vote for a wider range of newer, alternative parties - they have behaved more like discriminating consumers than committed partisans - thus contributing to the Westminster vote and seat fragmentation described in the previous section.

The decline of class-based voting. A second measurable factor that has contributed to party fragmentation in Westminster voting is the decline of social class as a source of voting choice. Traditionally, people from manual working class families disproportionately supported Labour whilst non-manual middle class voters disproportionately supported the Conservatives. Table 2 displays the relationship between vote and social class in 1964, and again in 2015. The contrast between the two elections could not be clearer. In 1964, just under two-thirds of middle class voters supported the Conservatives and a similar proportion of working class voters supported Labour: there was a very clear relationship between class and vote. By 2015, the class/vote nexus had weakened considerably. While the Conservatives garnered slightly more middle class votes (43\%) than working class ones (33\%), Labour's support was almost the same among the middle class (31\%) as it was among the manual working class (33\%). Class-based voting in fact declined progressively after 1964. Figure 10 reports a simple class/vote 'consistency index' that can be calculated, for every general election since 1964, from tables analogous to those shown in Table 2. The data for 2016 relate to voting intentions rather than reported vote. As the figure shows, class has all but disappeared as a factor in vote choice.

The mechanism through which declining class-voting contributes to party fragmentation is simple. Parties with a clear class base, of the sort enjoyed by Labour and the Conservatives from the 1930s to the 1960s, find it relatively easy to garner votes from that class demographic. But a third party challenger has to position itself to attract working class votes from Labour and/or middle class votes from the Conservatives. This is an extraordinarily difficult task to accomplish in constituencies of different types given that it is important to convey a consistent national-level campaigning message in order to present an image of 
policy and managerial competence. As class-based voting weakens, however, not only do the original class-based parties have to make new non-class appeals to attract support, but third parties too have an equal opportunity to make non-class appeals. In fact, as class-based voting declines, all parties increasingly have to engage in what Riker (1986) termed heresthetics - the conscious effort to focus political debates and divisions on 'new' issue dimensions or cleavages that are conducive to their own interests. The SNP, for example, have been outstandingly successful on re-structuring political debate in Scotland around Scottish interests and which party is best placed to advance them. The decline of class as the basis of the vote has simply created more opportunities for newer parties to frame issues and mobilise support on a more level playing field than previously - though FPTP still represents a constraining influence by restricting the 'fair' translation of national vote share into Westminster seats (for all but the SNP).

The implication of the foregoing discussion is that the long-term declines of party identification and class-voting have both played roles in the growing fragmentation of Westminster voting. Tables 3 and 4 test this proposition. Table 3 shows the correlations, across the 14 elections 1964-2015, between (a) changes in vote fragmentation and (b) changes in party identification and class-voting. PID is measured as the percentage of the electorate with no party identification; class-voting is measured using the Consistency Index outlined above. ${ }^{4}$ The table shows, as expected, that fragmentation is positively correlated with the proportion of the electorate with no party identification ( $\mathrm{r}=.89$ : as the proportion of Non-Identifiers has increased, fragmentation has increased)) and negatively correlated with class-vote ( $\mathrm{r}=-.93$ : as class-voting has declined, fragmentation has risen).

Table 4 reports two simple multivariate models of vote fragmentation, 1964-2015. The lefthand segment of Table 4 presents an OLS model which suggests that both PID $(b=.032)$ and Class-Vote $(b=-.014)$ exert statistically significant effects on fragmentation. However, inspection of the OLS model's residuals indicated that they are generated by a second order autoregressive process or AR(2). The right-hand segment of Table 4 accordingly reestimates the model as an $\mathrm{AR}(2)$. The results show that No Identification and Class-Vote continue to be statistically significant and correctly signed. With only 14 cases in this sort of time-series, it is risky to set too much store by statistical modelling of these relationships. However, the results are certainly consistent with the claim that the upward trend in fragmentation is significantly affected by the downward trends in PID and class-voting since 1964. This is not to say the 'unmeasurable' factors mentioned earlier are not also important merely that their effects cannot readily be assessed empirically, even in the imperfect manner described in Tables 3 and $4 .^{5}$

\section{Britain's current political tribes and the potential for a party-system re-alignment}

The referendum on the UK's membership of the European Union held in July 2016 highlighted the growing appeal of Authoritarian Populism (AP) among the British public. Indeed, since UKIP's emergence as an electoral force after the 2010 general election (and particularly after its performance in the May 2014 European Parliament elections), it has been clear that authoritarian populist sentiments have become an increasingly important feature of 
the UK political landscape. This is not to say that voting for extreme right-wing parties, or voting for UKIP, provides a simple measure of the extent of the electorate's AP thinking. Rather, AP is best viewed as a constellation of five sets of attitudes that relate to: the individual's position on the left-right ideological spectrum; cynicism about the importance and desirability of protecting human rights (which mainstream political parties take for granted); concern about and opposition to immigration (an issue, at least until recently, consistently underplayed by successive governments); opposition to the EU; and strong support for a robust national defence and foreign policy (see Sanders, Scotto and Reifler, 2016).

Table 5 reports the results of an exploratory factor analysis on five measures of AP attitudes. The results show clearly that a single dimension underlies the five measures. An alpha-scale test for uni-dimensionality among the same variable set yields $\alpha=0.75$ (above the standard 0.7 cut-off), suggesting that the five measures do indeed form an Authoritarian Populist scale on which any given individual can be located. Analyses of the consequences of AP, not reported here, show that net of the effects of other key predictors, AP attitudes have powerful effects on Westminster voting intention, EU referendum vote and democracy satisfaction.

The same AP measures can also be analysed using cluster analysis, to establish if there are groupings of individuals who constitute distinctive attitudinal types. It is not a simple task to decide how many clusters to estimate for any given set of variables and individuals. For the purposes of analysis here, 2-, 3-, 4- and 5-cluster solutions were estimated. The details are provided in Annex 3. The results there show that the 2-cluster solution fails to distinguish between two sorts of Authoritarian Populists - those in the centre of the political spectrum and those on the far right. Similarly, the 3-cluster solution fails to differentiate between centrist APs and centre-right liberals. The 5-cluster solution, in contrast, identifies one cluster that contains only $12(1 \%)$ of the 1265 respondents sampled - a sure sign that this grouping is insufficiently important to merit serious consideration as a distinct 'type'.

As Table 6 indicates, however, the 4-cluster solution tells a compelling story about the UK's new political tribes, and their relative sizes, in an era of renewed authoritarian populism. Note that this story reveals a subtlety about contemporary British political attitudes that would not be evident if only left/right ideology were considered. The table reports the mean scores on each of the five AP measures for each of the four clusters. With minor exceptions, the mean scores on each AP component measure increase as we move down the table from Liberal Internationalist Pro-EU Left to Authoritarian Populist Right. (For example the mean Critical of Human Rights score increases progressively from 2.08 to 3.83 as we move down the table). The only major exception - and this is where the importance of considering more than just left/right ideology is borne out - relates to the mean left/right scale score for the Liberal Pro-EU Centre-Right (6.28) - which is significantly higher than the equivalent score for the Authoritarian Populist Centre (5.02). In short, there is a sizeable group (estimated at $15 \%$ of the UK electorate) that is clearly to the right of the political spectrum but which equally clearly rejects AP attitudes and values. Together with the Liberal Internationalist Pro-EU Left (estimated at 37\%), these non-APs represent just over half of the electorate, compared with the two groupings of APs - the AP Centre (29\%) and the AP Right (19\%). 
The key issue that follows from the identification of these four groupings or clusters ('tribes') is what consequences they might have for changing patterns of party support. Table 7 reports the relationship between Tribe and Vote based on column percentages. As the table shows, almost two-thirds of Liberal Internationalists (65\%) support Labour, though to a lesser extent they also support the Liberal Democrats and Others (in effect, Greens, SNP and PC). The Liberal Pro-EU Centre-Right strongly supports the Conservatives (67\%) and to a lesser extent the Lib-Dems (17\%). The AP Centre distributes its support across the Conservatives (42\%), Labour (21\%) and UKIP (25\%). The AP Right is overwhelmingly Conservative (75\%), with most of the remainder supporting UKIP (21\%).

Table 8 reports the same data, but this time presenting row percentages. This enables us to analyse the spread of party support across the four tribes (now labelled as T1, T2, T3 and T4) more easily. The results are instructive. The Conservatives have the most diversified support portfolio, deriving substantial support from T2, T3 and T4. This degree of dispersal is potentially a source of long-term electoral strength, though it is possible that Theresa May's authoritarian tendencies with regard to immigration may combine with a 'hard Brexit' to alienate the remaining Conservative supporters in T2, the Liberal Pro-EU Centre-Right. Labour, in contrast, is largely dependent on T1 and risks losing its remaining supporters in T3 either to UKIP or to a newly authoritarian Conservative party that strengthens its opposition to immigration and human rights and at the same promises more redistribution. UKIP, which is dependent entirely on AP support, is clearly vulnerable to the Conservatives now that its original raison d'etre has gone and Euroscepticism dominates the Cabinet. Finally, the LibDems and Others are dependent primarily on the Liberal Internationalist T1 tribe for their support - and their efforts to increase their support levels there are likely to make life even more difficult for Jeremy Corbyn's increasingly sectarian Labour Party.

All of this suggests that the situation in the UK is ripe for a party realignment around the political centre. The Conservatives are clearly in a position to undercut UKIP and reinforce their support among the AP Centre and AP Right as the May government adopts a more aggressive foreign policy stance, stands firmly against immigration, and moves towards a hard Brexit. If there are no Tory defections from this increasingly authoritarian populist position, the Conservatives could become the dominant party of UK electoral politics. In these circumstances, however, the Conservative centre-left would have very little in common with anti-EU, anti-immigrant, anti-human-rights mainstream of the party. The Tory centreleft group in the Commons is almost certainly smaller than the 128 Conservative MPs who committed themselves formally to the Remain camp in the EU referendum. However, it is probably at least half that size, even after David Cameron's resignation as an MP. If the Tory centre-left could bring itself to put national interest above party loyalty (never a small matter!), it could defect to a new democratic centre party or even to the Lib-Dems, with a realistic possibility of bringing the support of most of the T2 tribe with them.

Labour under Corbyn, for its part, is likely to see its support increasingly restricted to T1, the Liberal Internationalist, Pro-EU Left. Even though T1 (with a 37\% share) is numerically the largest single tribe, Labour has to compete for T1 support with other liberal parties, and it is seriously hampered in its electoral efforts by widespread negative voter perceptions of both 
its leadership and its managerial competence. Corbyn's overwhelming victory in the party's leadership vote in October 2016 means that Labour's centre-left has lost its battle for control of the party. Like the liberal Tories who are isolated in an increasingly authoritarian populist Conservative party, Labour's centre-left MPs have less and less in common with a leadership that fails to understand voters' concerns about immigration, and which sees Labour primarily as an activist-driven campaigning party that articulates a radical voice for the dispossessed rather than as a (necessarily compromising) party of government. In these circumstances, Labour's centre-left should seriously consider defection. The empowerment of Labour's grass-roots constituency activists under the post-2014 leadership rules and Corbyn's victory together mean that Labour stands no prospect of occupying the political centre ground of British politics. If Labour's centre-left (the majority of its current MPs) allow party loyalty to dominate their actions, they seriously risk condemning the British electorate to the electoral hegemony of an increasingly authoritarian Conservative government in the future. If, on the other hand, they recognise that the need to protect liberal, internationalist values is more important than personal ambition and misplaced loyalty to a party that has moved radically to the left, then defection to a new centre party could provide a plausible vehicle for protecting those values. A new centre party (or a reconstructed Lib-Dem party) could realistically bid for dominance among T1 and T2 voters, giving it a serious chance of challenging the Conservatives in 2020.

\section{Summary and Conclusions}

The UK party system has always been subject to change and occasionally, as with the replacement of the Liberals by Labour in the 1920s, to fundamental change. Since the 1950s, the electorate has increasingly signalled its collective preference, even at Westminster, for a more multi-party system. The Number of Effective Parties in terms of votes has increased from two in 1951 to almost four in 2015. To be sure, First-Past-the-Post has constrained the seat shares of alternative parties so that even by 2015 the Number of Effective Parties in terms of seats had risen to only 2.5 .

With regard to the 'measurable' influences on this increasing fragmentation of voting preferences, the key drivers of change appear to have been the declines in class voting and party identification. Declining class voting increases the opportunities for alternative parties to open up new issues and cleavages while declining party identification makes more voters available for recruitment to alternative causes. In both cases, third parties can compete more effectively thereby increasing vote-fragmentation. These 'measurables' have almost certainly been complemented by such 'unmeasurables' as the rise of alternative identities and increased media and social media criticism of politicians and conventional politics. These effects have been reinforced by certain decisions of party leaders that have added to the deeper centrifugal forces encouraging party fragmentation. In Labour's case, the decision to move to genuine One-Member-One-Vote in 2014, combined with a naïve approach to the Leader nomination by the Parliamentary Labour Party after the 2015 general election defeat, has enabled left-wing grassroots activists to take control of the party. This is a position they will not lightly relinquish but it has seriously (some would argue, fatally) weakened Labour's 
electoral prospects by shifting the party's centre of political gravity too far away both from Labour's traditional support base and from the median voter. As far as the Conservatives are concerned, Cameron's overweening confidence and unpreparedness to listen to advice in committing to a referendum on Britain's EU membership and his subsequent failure properly to prepare public opinion before calling the referendum itself were hugely damaging to the project he was seeking to advance. They led to the termination of his pro-EU liberal leadership of the party and its replacement by a more hardline anti-EU and authoritarian May government.

Underpinning the rise of UKIP since 2010 and the Leave victory in June 2016 has been the growth of Authoritarian Populist sentiment among the UK electorate. Indeed, Authoritarian Populist attitudes (and their antitheses) now constitute an important defining dimension of UK public opinion and electoral politics. Cluster analysis of these AP attitudes suggests there are now four 'tribes' of UK voters: the Liberal Internationalist Pro-EU Left; the Liberal, Pro-EU Centre-Right; the Authoritarian Populist Centre; and the Authoritarian Populist Right. Under Corbyn, Labour's support base in the Liberal Internationalist Pro-EU Left is far too limited for it to prosper electorally - especially as it faces competition from other liberal parties such as the Lib-Dems, the SNP and Plaid among that group of voters. At the same time, liberal pro-EU Conservatives have little in common with an Authoritarian Populistdominated Conservative leadership that appears bent on hard Brexit and which draws most of its electoral support from the AP Centre and AP Right. Indeed, on the key issues of Europe, human rights, immigration and the fiscally responsible mixed economy, the Conservative centre has much more in common with the vast majority of anti-Corbyn Labour MPs than it does with its own government and party activists. Conservatives do not have a history of splitting and Labour activists and MPs have a visceral fear (if not hatred) of it. However, the long-term loosening of party identifications and of class-based voting outlined above have created a new situation that is very different from previous occasions (such as 1931 or 1981) when serious splits in the major parties have been on the political agenda.

Fundamental policy differences within the two main parties are becoming increasingly evident. Combined with the new divisions in the electorate associated with the four tribes described above, Conservative and Labour centre liberals would have little to lose and much to gain by defecting from their respective parties. To avoid more party fragmentation and the vicious circle consequences of First-Past-the-Post, they could explore the possibility of working with the Liberal-Democrats to form a new party of the liberal, democratic centre. Such a party grouping could expect to prosper in a general election, especially with Rump Labour fighting UKIP for working class votes in the North and Midlands and the Conservatives and UKIP competing for Authoritarian Populist votes across the country. For the neutral observer, the spectacle would be irresistible. 
Figure 1: Conservative, Labour, Liberal (Democrat) and Other Parties Vote Shares in General Elections, 1832-2015

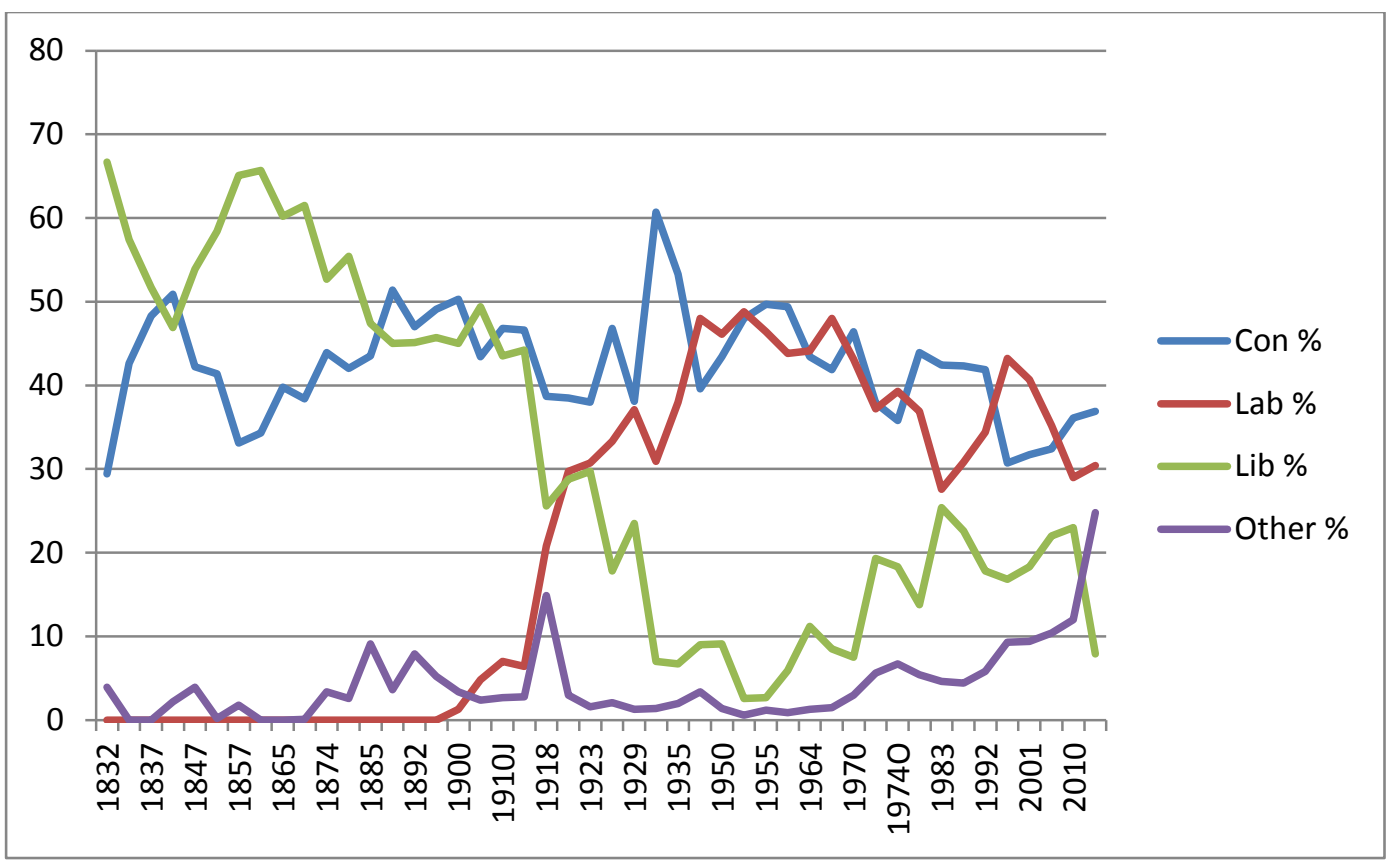

Source: David Butler and Gareth Butler, British Political Facts (Basingstoke: PalgraveMacmillan, 2011) and, for 2015, www.bbc.co.uk/news/election/2015/results.

Figure 2: SNP Vote Share in Scotland and Plaid Cymru Vote Shares in Wales in UK general elections, 1929-2016

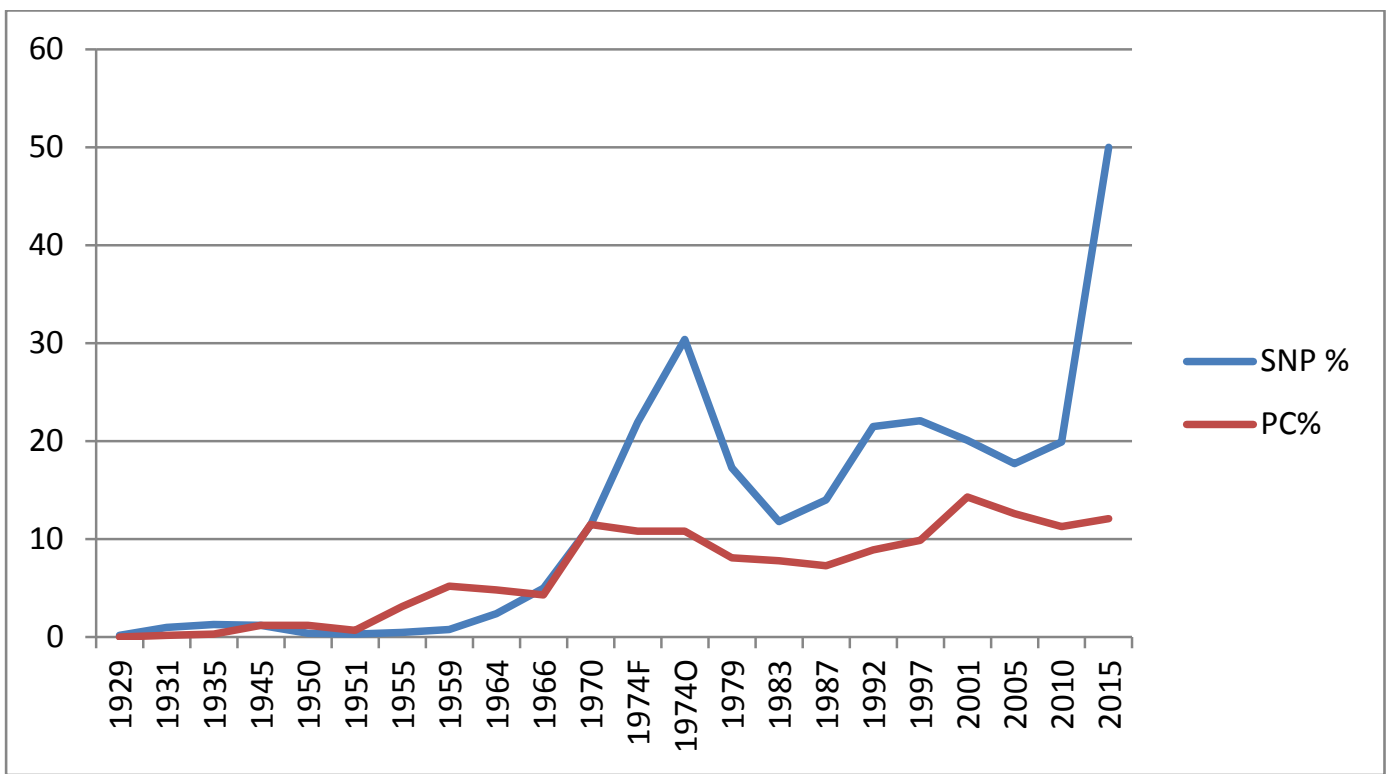

Source: see Figure 1 
Figure 3: Party Vote Shares (List Vote) in Scottish Parliament Elections, 1999-2016

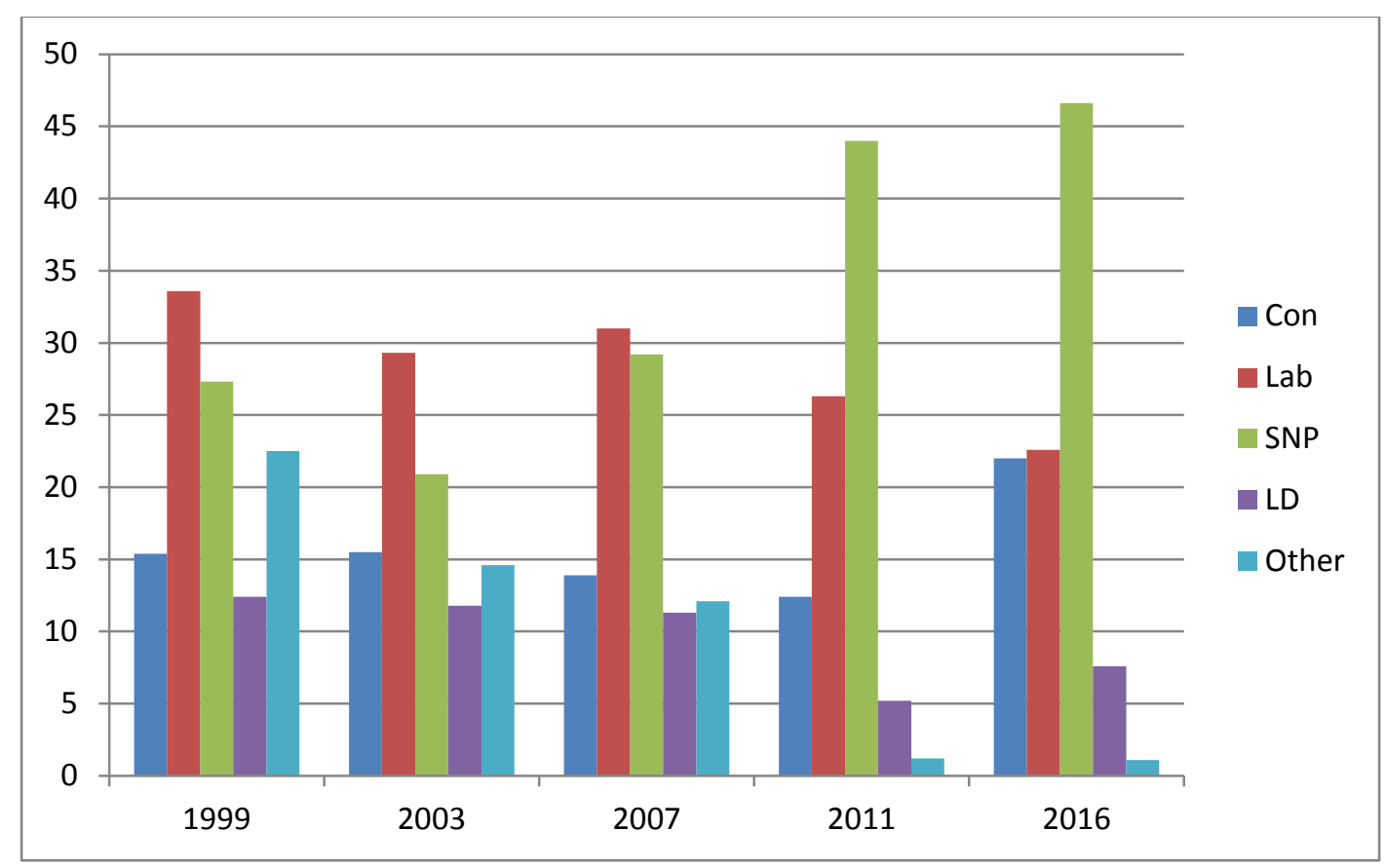

Source: $\underline{\text { https://en.wikipedia.org/wiki/Scottish_Parliament_election }}$

Figure 4: Party Vote Shares (List Vote) in Welsh Assembly Elections, 1999-2016

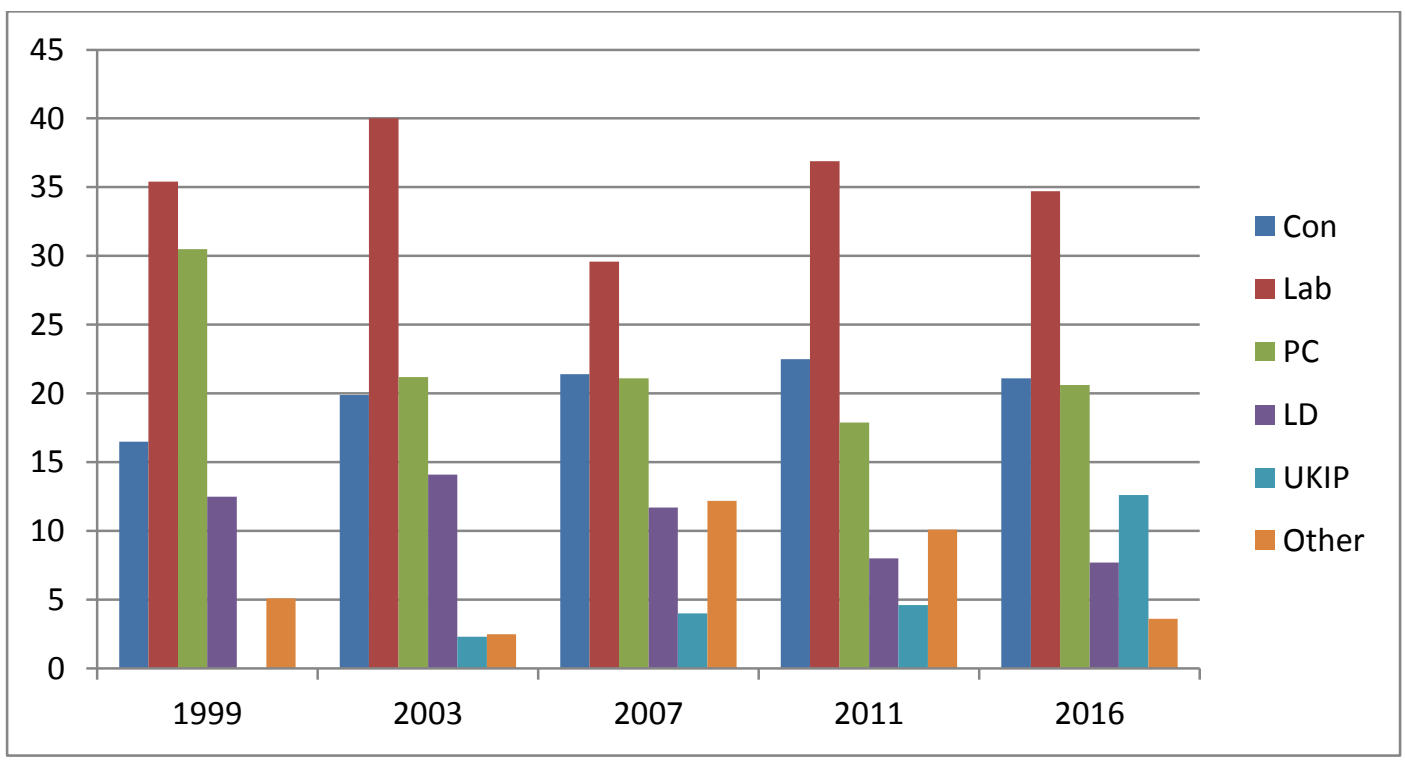

Source: https://en.wikipedia.org/wiki/National_Assembly_for_Wales_election 
Figure 5: Party Vote Shares (List Vote) in Northern Ireland Assembly Elections, 19982016

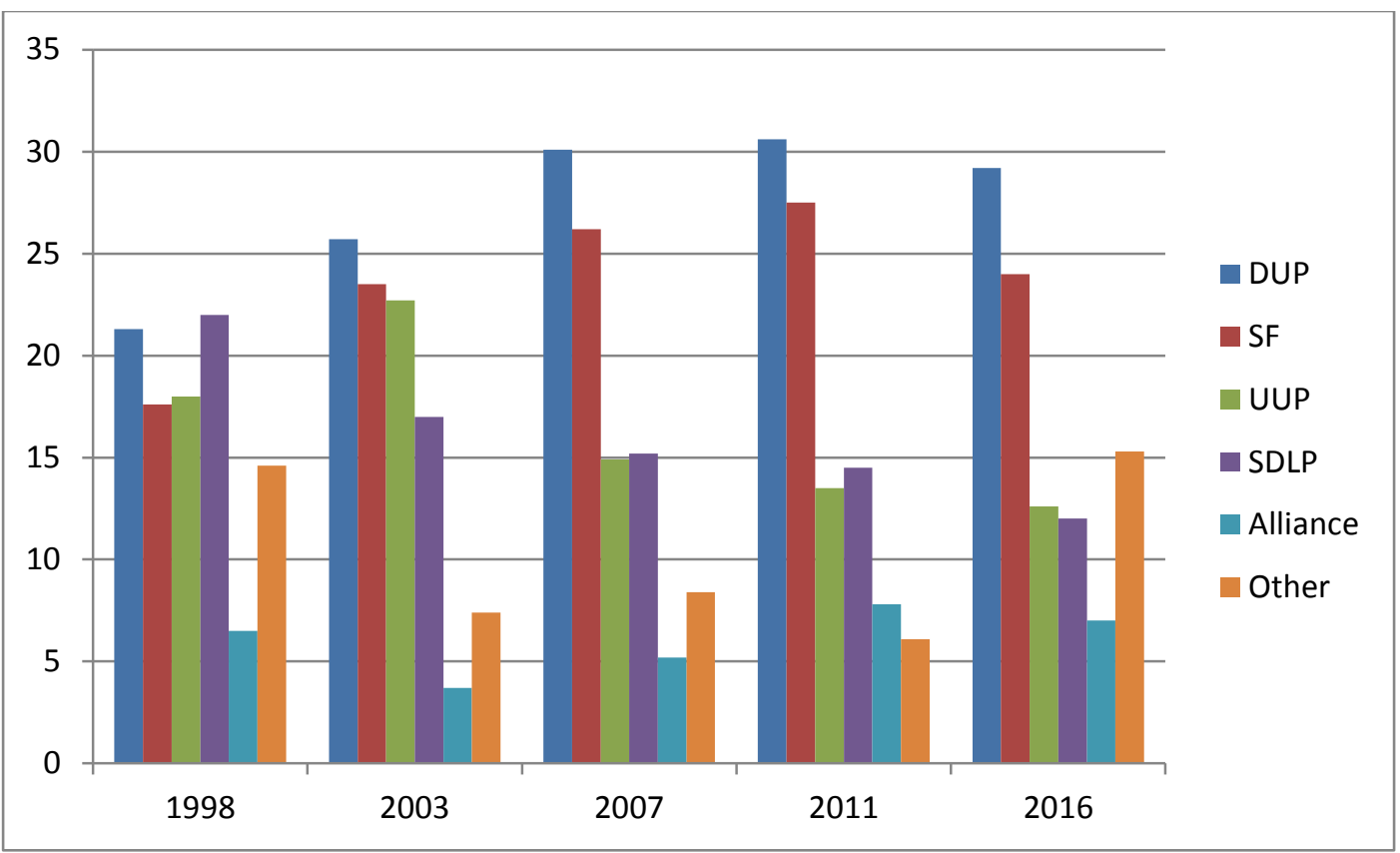

Source: https://en.wikipedia.org/wiki/Elections_in_Northern_Ireland

Figure 6: Number of Major UK Cities with No Overall Control, 1945-2016 ( $\mathrm{N}=22)$

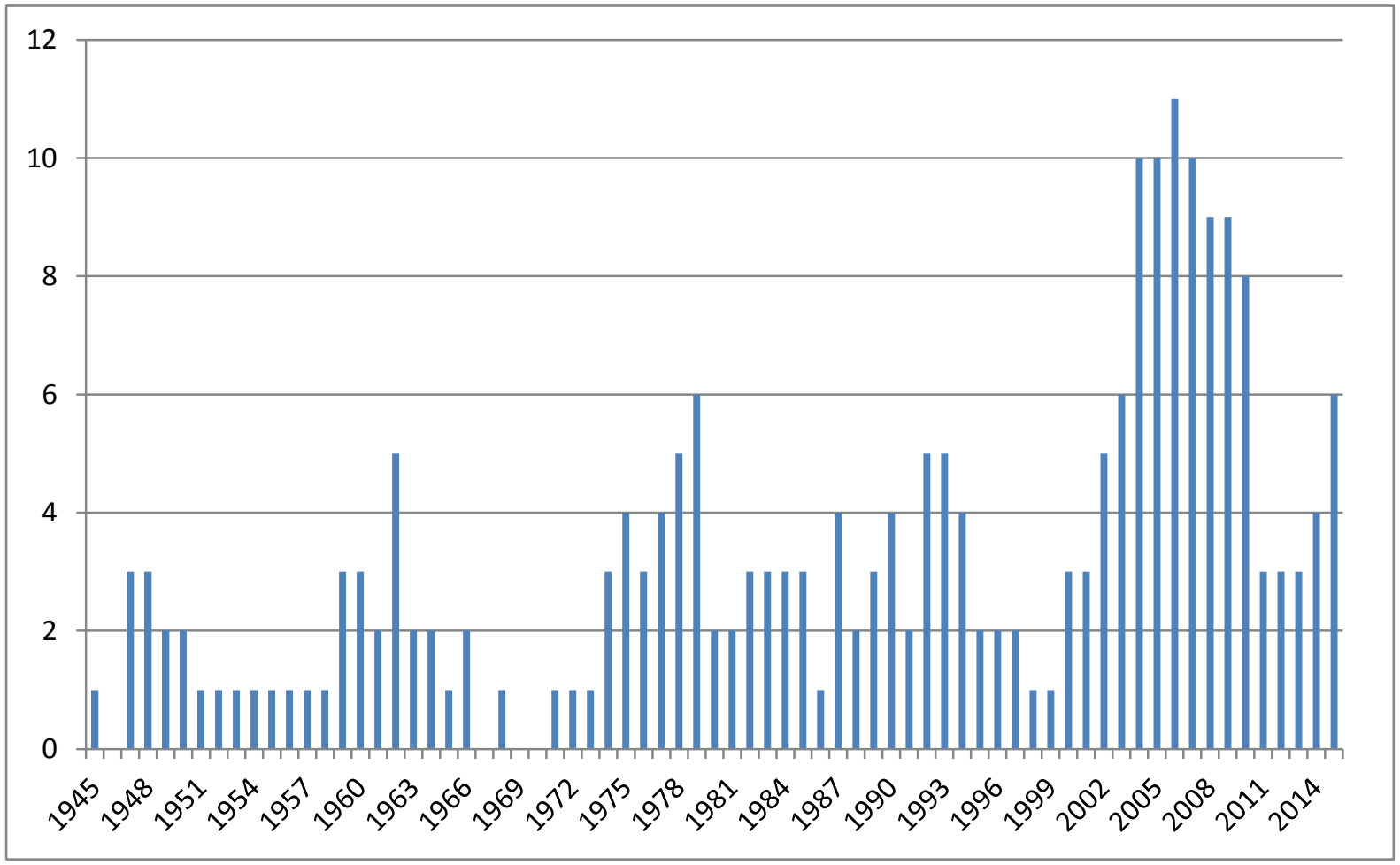

Source: See Figure 1 and Colin Rallings and Michael Thrasher 
Figure 7: Effective Number of Parties in terms of Votes and Seats, UK 1900-2015

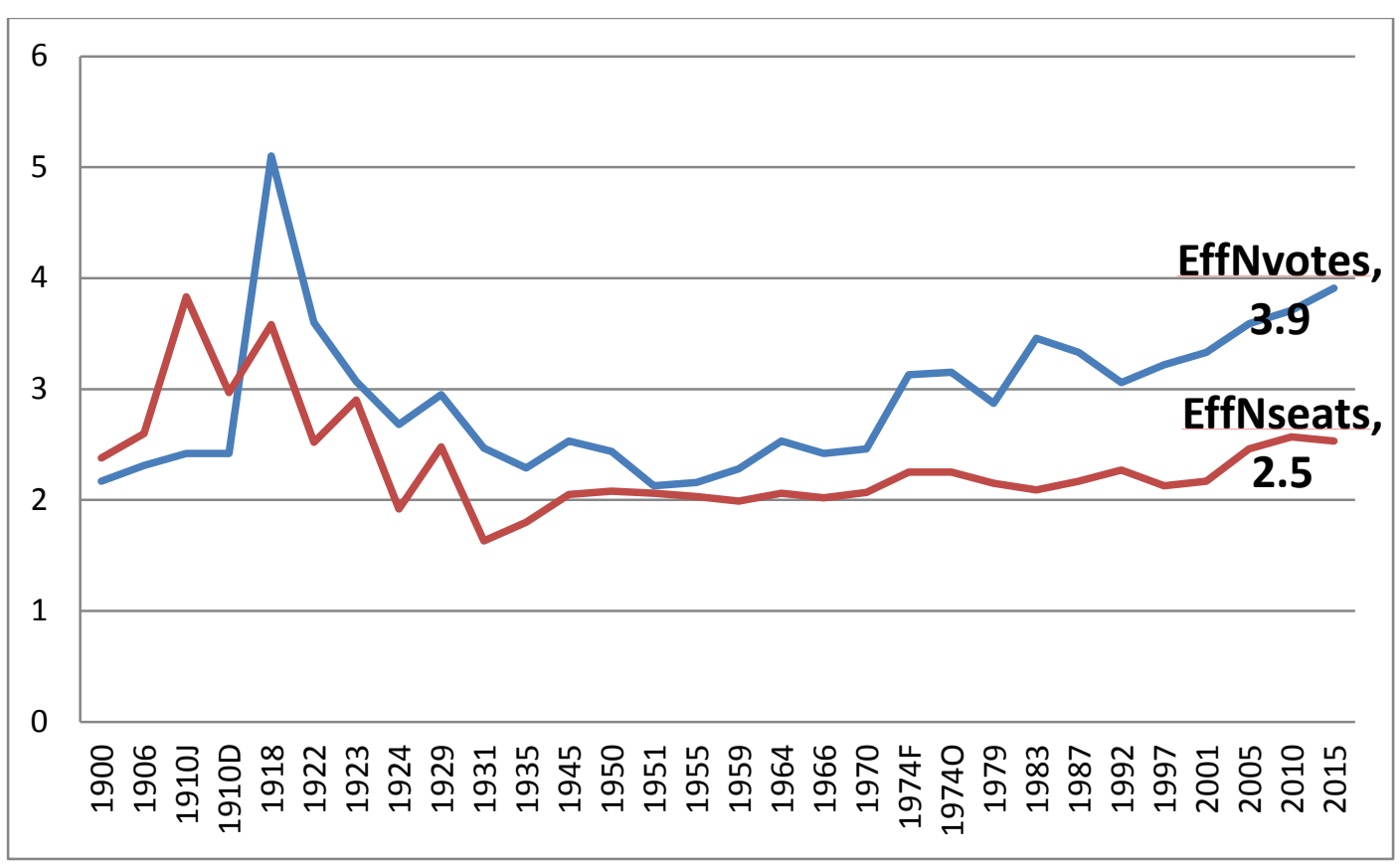

Source: http://www.tcd.ie/Political_Science/staff/michael_gallagher/ElSystems/ and own calculations from sources cited in Figure 1

Figure 8: Percent Very Strong, Fairly Strong, Not Very Strong and No Party Identifiers, 1964-2015

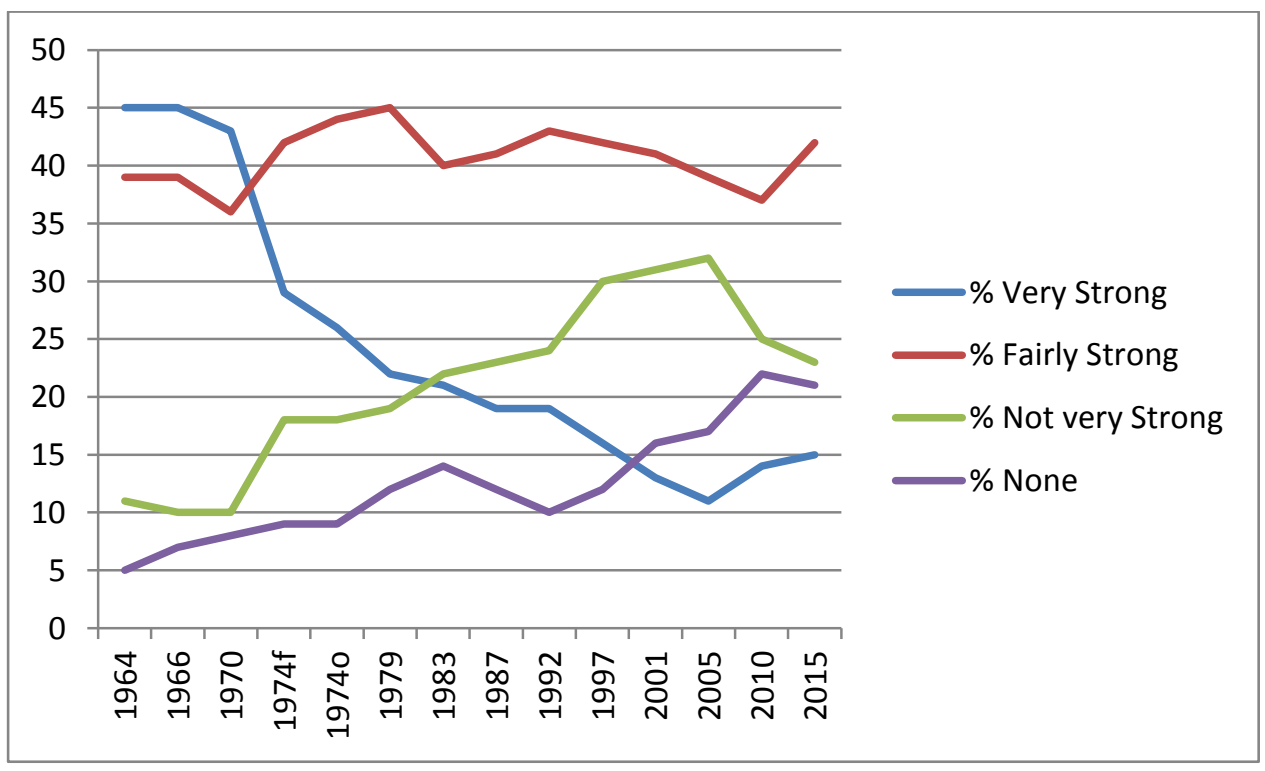

Source: BES cross-section surveys, 1964-2015 
Figure 9: Strength of Party Identification with Conservative, Labour and Liberal Democrat Parties, 1964-2015

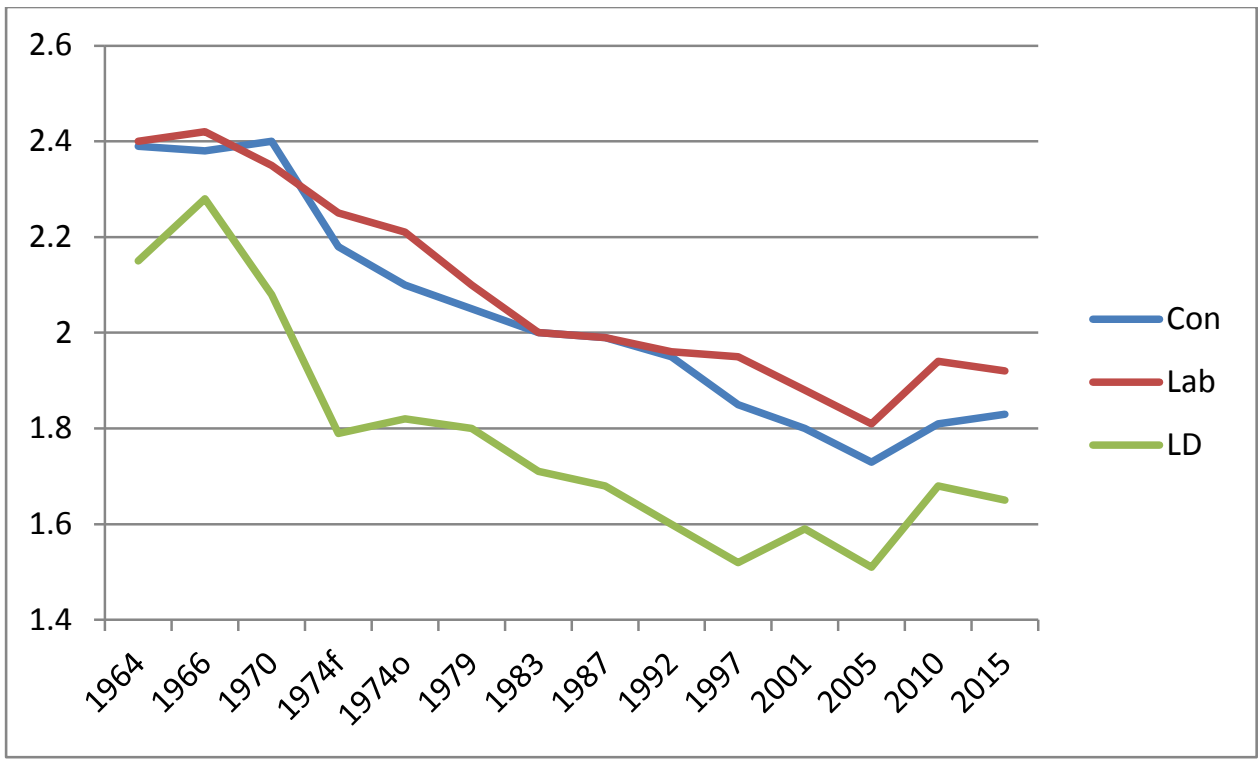

Source: BES cross-section surveys, 1964-2015. The index figure reported are calculated as averages of individual scores where Very Strong Identification with a party scores 3; Fairly Strong scores 2; Not Very Strong scores 1; and No identification scores 0. 
Table 1: Effective Number of Parties (EPN) in terms of Votes and Seats and Gallaher Disproportionality Index Measures; Devolved Assembly Averages, 1998-2016

\begin{tabular}{|l|l|l|l|l|}
\hline & ENP-votes & $\begin{array}{l}\text { ENP- } \\
\text { seats }\end{array}$ & $\begin{array}{l}\text { Gap votes- } \\
\text { seats }\end{array}$ & $\begin{array}{l}\text { Gallaher } \\
\text { Index }\end{array}$ \\
\hline Northern Ireland Average, 1998-2016 & 5.11 & 4.54 & 0.57 & 3.61 \\
\hline Scotland Average, 1999-2016 & 4.27 & 3.32 & 1.05 & 7.00 \\
\hline Wales Average, 1999-2016 & 4.40 & 3.07 & 1.33 & 10.36 \\
\hline
\end{tabular}

Source: own calculations based on data as in Figures 3-5

Table 2: Class voting in the 1964 and 2015 General Elections

\begin{tabular}{|l|c|c|}
\hline 1964 & $\begin{array}{c}\text { Non-Manual } \\
\text { Middle Class }\end{array}$ & $\begin{array}{c}\text { Manual } \\
\text { Working Class }\end{array}$ \\
\hline Conservative & $62(\mathrm{a})$ & 28 (b) \\
\hline Labour & $22(\mathrm{c})$ & $64(\mathrm{~d})$ \\
\hline Other & 16 & 8 \\
\hline Class Consistency Index & \multicolumn{2}{|c|}{76} \\
\hline \multicolumn{3}{|c|}{} \\
\hline $\mathbf{2 0 1 5}$ & $\begin{array}{c}\text { Non-Manual } \\
\text { Middle Class }\end{array}$ & $\begin{array}{c}\text { Manual } \\
\text { Working Class }\end{array}$ \\
\hline Conservative & 43 & 33 \\
\hline Labour & 31 & 33 \\
\hline Other & 26 & 34 \\
\hline Class Consistency Index & \multicolumn{2}{|c|}{12} \\
\hline
\end{tabular}

Source: BES cross-sections, 1964 and 2015. Column Percentages reported. Class

Consistency Index is measured as $(a-b)+(d-c)$ [Theoretical range $0-200$ ]

Table 3: Correlations between (a) Effective Number of Parties-Votes and (b) No Party Identification and Class-Voting

\begin{tabular}{|l|c|}
\hline & $\begin{array}{c}\text { Fragmentation: } \\
\text { Effective Number } \\
\text { of Parties-Votes }\end{array}$ \\
\hline Percent No Party Identification & +.89 \\
\hline Class-Vote Consistency Index & -.93 \\
\hline
\end{tabular}

$\mathrm{N}=14$ (cases are general elections 1964-2015). Source: own calculations 
Table 4: Models of Party Fragmentation (Effective Number of Parties-Votes), 19642015, OLS and Autoregressive Specifications

\begin{tabular}{|l|l|l|l|l|l|l|l|}
\hline & \multicolumn{3}{|c|}{ OLS Model } & \multicolumn{3}{c|}{ AR(2) Model } \\
\hline & Coeff & St Err & Sig & Coeff & St Err & Sig \\
\hline Percent No Party Identification & 0.032 & .016 & .064 & 0.031 & .016 & .013 \\
\hline Class Voting Consistency Index Score & -0.014 & .004 & .004 & -0.015 & .003 & .000 \\
\hline Constant & 3.430 & .374 & .000 & 3.450 & .254 & .000 \\
\hline $\mathrm{U}_{\mathrm{t}-1}$ & & & & -0.509 & & .054 \\
\hline $\mathrm{U}_{\mathrm{t}-2}$ & & & & -0.510 & & .054 \\
\hline Corrected R2 & 0.887 & & & 0.917 & & \\
\hline Durbin Watson & 2.684 & & & 2.350 & & \\
\hline
\end{tabular}

Dependent variable is Effective Number of Parties in terms of Votes. Sample: General Election Events 1964-2015. N=14

Table 5: Exploratory Factor Analysis of Five Indicators of Authoritarian Populism, 2016

\begin{tabular}{|l|c|c|c|}
\hline Component Variable & Range & Loading & Uniqueness \\
\hline Left/Right self-placement & $0-10$ & 0.59 & 0.65 \\
\hline Britain Strong and Tough Foreign Policy & $0-1$ & 0.54 & 0.71 \\
\hline Negative emotions on immigration & $0-4$ & 0.67 & 0.54 \\
\hline Critical of Human Rights & $1-5$ & 0.73 & 0.47 \\
\hline Disapproval of EU & $1-5$ & 0.73 & 0.47 \\
\hline
\end{tabular}

Eigenvalue Factor $1=2.15$; Factor $2=0.02 . \mathrm{N}=1265$. For precise variable definitions see Annex 4. Source: YouGov 12-Nation Authoritarian Populism Survey, October 2016

Table 6: The UK electorate's four political tribes: four-cluster solution

\begin{tabular}{|c|c|c|c|c|c|c|}
\hline Cluster & $\begin{array}{c}\text { Foreign } \\
\text { Policy } \\
\text { Strong and } \\
\text { Tough }\end{array}$ & $\begin{array}{c}E U \\
\text { Disapproval }\end{array}$ & $\begin{array}{c}\text { Critical } \\
\text { of } \\
\text { Human } \\
\text { Rights }\end{array}$ & $\begin{array}{c}\text { Negative } \\
\text { Immigration } \\
\text { Emotions }\end{array}$ & $\begin{array}{l}\text { Left/Right } \\
\text { Scale }\end{array}$ & $\begin{array}{l}\text { Per } \\
\text { cent }\end{array}$ \\
\hline $\begin{array}{l}\text { Liberal } \\
\text { Internationalist } \\
\text { Pro-EU Left }\end{array}$ & .10 & 1.79 & 2.08 & .31 & 3.07 & 37 \\
\hline $\begin{array}{l}\text { Liberal Pro-EU } \\
\text { Centre-Right }\end{array}$ & .26 & 1.77 & 2.84 & .68 & 6.28 & 15 \\
\hline $\begin{array}{l}\text { Authoritarian } \\
\text { Populist Centre }\end{array}$ & .44 & 4.36 & 3.65 & 1.72 & 5.02 & 29 \\
\hline $\begin{array}{l}\text { Authoritarian } \\
\text { Populist Right }\end{array}$ & .53 & 4.46 & 3.83 & 1.71 & 7.79 & 19 \\
\hline $\begin{array}{l}\text { Average } \\
\text { (range) }\end{array}$ & $\begin{array}{c}.30 \\
(0-1)\end{array}$ & $\begin{array}{l}2.96 \\
(1-5)\end{array}$ & $\begin{array}{l}2.94 \\
(1-5)\end{array}$ & $\begin{array}{l}1.00 \\
(0-3)\end{array}$ & $\begin{array}{c}4.96 \\
(0-10)\end{array}$ & \\
\hline
\end{tabular}

Source: YouGov 12-Nation Authoritarian Populism Survey, October 2016 
Table 7: Vote Intention by Political Tribe 2016, Column Percentages

\begin{tabular}{|l|c|c|c|c|}
\hline & $\begin{array}{c}\text { Liberal } \\
\text { Internationalist } \\
\text { Pro-EU Left (37\%) }\end{array}$ & $\begin{array}{c}\text { Liberal Pro- } \\
\text { EU Centre- } \\
\text { Right (15\%) }\end{array}$ & $\begin{array}{c}\text { Authoritarian } \\
\text { Populist } \\
\text { Centre (29\%) }\end{array}$ & $\begin{array}{c}\text { Authoritarian } \\
\text { Populist Right } \\
(19 \%)\end{array}$ \\
\hline Conservative & 7 & 67 & 42 & 75 \\
\hline Labour & 65 & 17 & 21 & 0 \\
\hline LibDem & 12 & 9 & 4 & 0 \\
\hline UKIP & 1 & 0 & 25 & 21 \\
\hline Other & 16 & 6 & 8 & 3 \\
\hline
\end{tabular}

Source: YouGov 12-Nation Authoritarian Populism Survey, October 2016

Table 8: Vote Intention by Political Tribe 2016, Row Percentages

\begin{tabular}{|l|c|c|c|c|}
\hline & $\begin{array}{l}\text { T1: Liberal } \\
\text { Internationalist } \\
\text { Pro-EU Left }\end{array}$ & $\begin{array}{l}\text { T2: Liberal } \\
\text { Pro-EU } \\
\text { Centre-Right }\end{array}$ & $\begin{array}{c}\text { T3: } \\
\text { Authoritarian } \\
\text { Populist Centre }\end{array}$ & $\begin{array}{c}\text { T4: } \\
\text { Authoritarian } \\
\text { Populist Right }\end{array}$ \\
\hline Conservative & 7 & 25 & 29 & 39 \\
\hline Labour & 75 & 8 & 17 & 0 \\
\hline LibDem & 63 & 20 & 16 & 1 \\
\hline UKIP & 2 & 0 & 59 & 38 \\
\hline Other & 62 & 10 & 21 & 7 \\
\hline
\end{tabular}

Source: YouGov 12-Nation Authoritarian Populism Survey, October 2016 


\section{References}

Clarke, Harold, David Sanders, Marianne Stewart and Paul Whiteley, 2004. Political Choice in Britain. Cambridge: Cambridge University Press Harold Carke, David Sanders and Marianne Stewart.

Duverger, Maurice. 1954. Political Parties: Their Organisation and Activity in the Modern State. London: Methuen.

Gallagher, Michael. 1991. Proportionality, Disproportionality and Electoral Systems. Comparative Political Studies. 10 (1): 33-51.

Gallagher, Michael and Paul Mitchell (eds). 2008. The Politics of Electoral Systems. Oxford: Oxford University Press.

Heath, Anthony, Stephen Fisher, Gemma Rosenblatt, David Sanders and Maria Sobolewska. 2013. The Political Integration of Ethnic Minorities in Britain. Oxford: Oxford University Press,

Isernia, Pierangelo, Irena Fiket, Fabio Serriccchio and Bettina Westle. 2012. But Still it Does Not Move: Functional and Identity-Based Determinants of European Identity. In David Sanders, Pedro Magalhaes and Gabor Toka (eds), Citizens and the European Polity: Mass Attitudes Towards the European and National Polities. Cambridge: Cambridge University Press, 110-139.

Laakso, Markku and Rein Taagepera. 1979. "Effective" number of parties: a measure with application to west Europe. Comparative Political Studies 12 (1): 3-27.

Nevitte, Neil. 2011. The Decline of Deference Revisited: Evidence after 25 Years. Paper presented at Mapping and Tracking Global Value Change: A Festschrift Conference for Ronald Inglehart, University of California, Irvine, March 112011.

Riker, William. 1986. The Art of Political Manipulation. New Haven: Yale University Press. Sanders, David, Thomas Scotto and Jason Reifler. 2016. The Consequences of Authoritarian Populism in Britain. Working paper, Department of Government, University of Essex. Whiteley, Paul, Harold Clarke, David Sanders and Marianne Stewart. 2013. Affluence, Austerity and Electoral Change in Britain. Cambridge: Cambridge University Press 


\section{Electronic Annexes}

Annex 1: The Trend in UK Government Popularity, 1947-2016

Figure A1: Monthly Variations in Government Popularity, January 1947 - August 2016

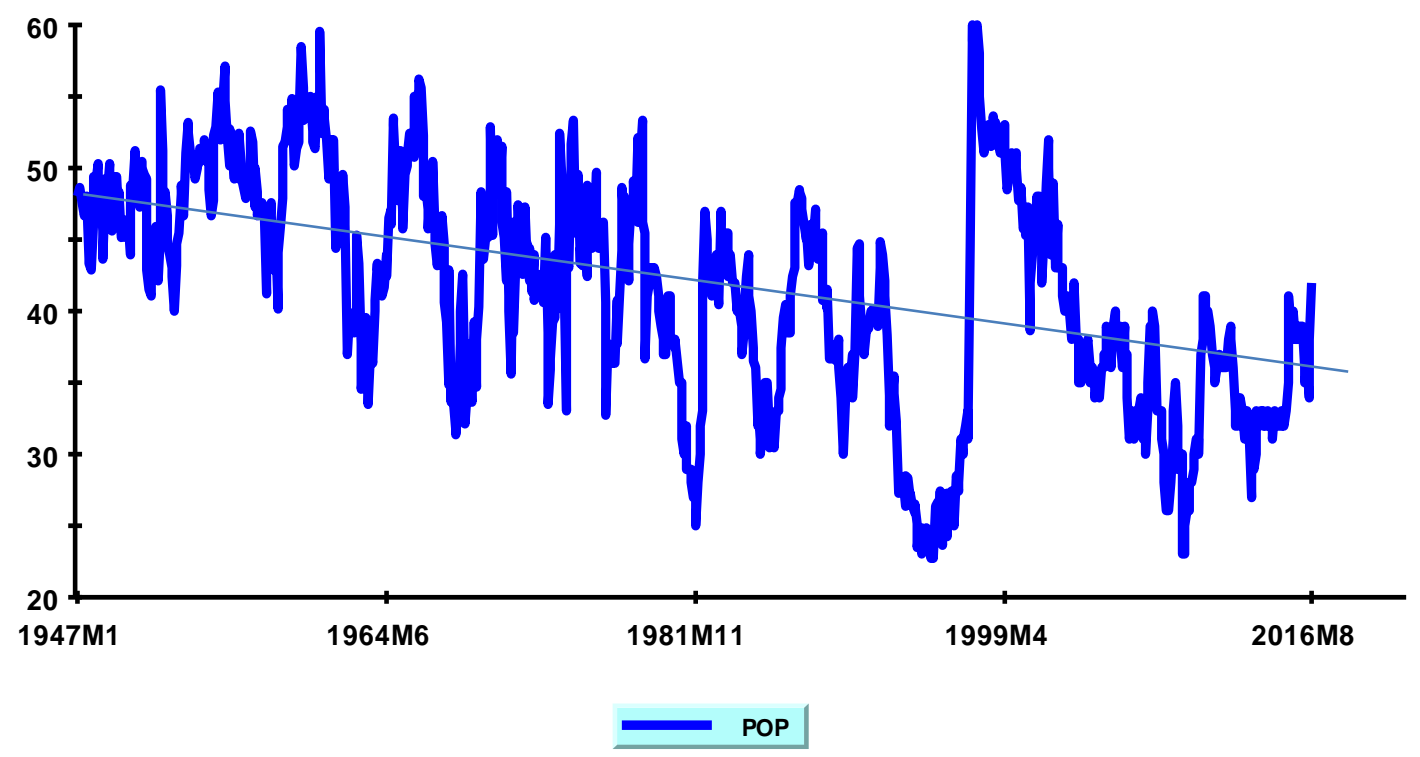

Government Popularity measured as the percent intending vote for the governing party, average of all published opinion polls. For the period of the 2010-2015 coalition government, the figures are Conservative vote intention.

A simple trend function can be estimated as Government Popularity $=49.34-0.19$ Time. Both the constant and the coefficient are significant at $\mathrm{p}<.000 ; \mathrm{r} 2$ is -.33 . The more elaborate specification outlined in the table above includes controls for the major political events of the 1947-2016 period.

Table A1: Lagged Endogenous Variable Model of UK Government Popularity 19472016, with controls for Key Political Events

\begin{tabular}{|l|l|l|l|}
\hline & Coefficient & Std Error & Significance \\
\hline Government Popularity t-1 & 0.94 & 0.01 & .000 \\
\hline Time & 0.001 & 0.0003 & .002 \\
\hline Change of government dummy & 4.46 & 0.88 & .000 \\
\hline Suez Crisis (November 1956) & 3.95 & 2.40 & .100 \\
\hline Devaluation Crisis (October 1967) & -4.84 & 2.40 & .044 \\
\hline
\end{tabular}




\begin{tabular}{|l|l|l|l|}
\hline Winter of Discontent (December 1978-March 1979) & -2.70 & 1.02 & .008 \\
\hline Falklands War (May, June 1982) & 6.72 & 1.54 & .000 \\
\hline Poll Tax (March 1990) & -4.80 & 2.40 & .046 \\
\hline ERM crisis (October 1992) & -5.25 & $2 / 40$ & .029 \\
\hline New Labour boost (May 1997) & 7.01 & 2.82 & .013 \\
\hline Blair Honeymoon (May-October 1997) & 3.75 & 0.94 & .000 \\
\hline Fuel crisis (September 2000) & -6.55 & 2.40 & .007 \\
\hline Iraq War (May 2003) & -2.97 & 2.40 & .216 \\
\hline Financial Crisis (November 2007) & -5.87 & 2.40 & .015 \\
\hline Expenses Scandal (May 2009) & -7.37 & 2.40 & .002 \\
\hline Constant & 2.84 & 0.55 & .000 \\
\hline Ut-1 & -.22 & 6.42 & .000 \\
\hline Ut-2 & -.05 & 1.33 & .184 \\
\hline Corrected R2 & 0.91 & & \\
\hline Durbin Watson & 2.00 & & \\
\hline Depent varibl Govin & \\
\hline
\end{tabular}

Dependent variable is Government Popularity, monthly average intending to vote for governing party as indicated by the average of all monthly polls. Estimation by Exact AR(2) Newton-Raphson Iterative Method after OLS diagnostics showed that the OLS residuals were generated by an $\mathrm{AR}(2)$ process. All independent variables other than lagged dependent variable are dummies (1 for the months specified; zero otherwise). Sample: 1947M2$2016 \mathrm{~m} 8 ; \mathrm{N}=835$.

The results in the table show that the time trend effect remains significant even when a lagged endogenous variable term and a battery of other effects and controls are included in the specification. 


\section{Annex 2: Lagged Models of Party Fragmentation (Effective Number of Parties-Votes), Party Identification and Class-Voting, 1964-2015}

When variables are potentially reciprocally related, Granger causality tests can be used to shed light on claims that any causal connection from $\mathrm{X}$ to $\mathrm{Y}$ rather than from $\mathrm{Y}$ to $\mathrm{X}$. The simplest way of effecting such tests is to see if lagged values of $X\left(e . g . X_{t-1}\right)$ predict $Y_{t}$ and/or if lagged values of $Y$ predict $X_{t}$. We could conclude $X$ affected $Y$, for example, if $X_{t-1}$ predicted $\mathrm{Y}_{\mathrm{t}}$ but $\mathrm{Y}_{\mathrm{t}-1}$ did not predict $\mathrm{X}_{\mathrm{t}}$. Table $\mathrm{A} 2$ undertakes these tasks. The coefficients of interest and their associated significance levels are highlighted in yellow. As the Table indicates, lagged (t-1) values of No Identification and Class Vote both significantly affect EPNVotes at time $t$ but lagged values of EPNVotes do not significantly affect either No Identification of ClassVote. These results clearly support the idea that it is PID and Classvote that affect party fragmentation rather than vice versa.

Table A2: Lagged Endogenous Variable Models of EPNVotes, No Identification and Class-Vote, 1964-2015

\begin{tabular}{|l|c|c|c|c|c|c|c|c|c|}
\hline & \multicolumn{3}{|c|}{ EPNVotes $_{\mathbf{t}}$} & \multicolumn{3}{c|}{ No PID $_{\mathrm{t}}$} & \multicolumn{3}{c|}{ ClassVote $_{\mathrm{t}}$} \\
\hline & Coeff & St Err & Sig & Coeff & St Err & Sig & Coeff & St Err & Sig \\
\hline EPNVotes $_{\mathrm{t}-1}$ & -.60 & .32 & .09 & -5.89 & 3.98 & .17 & 3.97 & 18.93 & .84 \\
\hline No PID $_{\mathrm{t}-1}$ & .08 & .02 & .00 & .91 & .25 & .01 & -2.32 & 1.17 & .08 \\
\hline ClassVote $_{\mathrm{t}-1}$ & -.02 & .01 & .03 & -.16 & .08 & .08 & .49 & .38 & .23 \\
\hline Constant & 4.29 & 1.18 & .00 & 28.39 & 14.57 & .08 & 35.77 & 69.24 & .62 \\
\hline Corrected R & .86 & & & & & & & & \\
\hline DW & 2.02 & & & 2.00 & & & 2.08 & & \\
\hline LM $\left(\mathrm{X}^{2}\right) 1$ & .06 & & .80 & .01 & & .90 & .66 & & .42 \\
\hline
\end{tabular}

Sample: general election events 1964-2015. N=13. Estimation by OLS. EPNVotes is the Effective Number of Parties in terms of Votes cast. No Identification is the Percentage of Non-Party-Identifiers in each BES cross-sectional survey. ClassVote is the Class-Voting Consistency Index.

The raw data for these estimates are as follows:

\begin{tabular}{|l|l|l|l|}
\hline Election & EPNVotes & No Identification & Class Vote \\
\hline 1964 & 2.53 & 5 & 76 \\
\hline 1966 & 2.42 & 7 & 83 \\
\hline 1970 & 2.46 & 8 & 78 \\
\hline $1974 \mathrm{f}$ & 3.13 & 9 & 50 \\
\hline $1974 \mathrm{o}$ & 3.15 & 9 & 51 \\
\hline 1979 & 2.87 & 12 & 42 \\
\hline 1983 & 3.46 & 14 & 45 \\
\hline 1987 & 3.33 & 12 & 43 \\
\hline 1992 & 3.06 & 10 & 46 \\
\hline 1997 & 3.22 & 12 & 36 \\
\hline 2001 & 3.33 & 16 & 37 \\
\hline 2005 & 3.59 & 17 & 28 \\
\hline 2010 & 3.71 & 22 & 34 \\
\hline 2015 & 3.91 & 21 & 12 \\
\hline
\end{tabular}


Annex 3: Cluster Analyses of UK Respondents, based on the five Authoritarian Populism Measures

\begin{tabular}{|l|l|l|l|l|l|l|}
\hline $\begin{array}{l}\text { Cluster } \\
\text { Solution }\end{array}$ & $\begin{array}{l}\text { Percentage } \\
\text { in Cluster }\end{array}$ & $\begin{array}{l}\text { Left-Right } \\
\text { Self } \\
\text { Placement }\end{array}$ & $\begin{array}{l}\text { Britain } \\
\text { Strong } \\
\text { and } \\
\text { Tough }\end{array}$ & $\begin{array}{l}\text { Negative } \\
\text { Immigration } \\
\text { Emotions }\end{array}$ & $\begin{array}{l}\text { Critical of } \\
\text { Human } \\
\text { Rights }\end{array}$ & $\begin{array}{l}\text { Disapproval } \\
\text { of European } \\
\text { Union }\end{array}$ \\
\hline 2-clusters & & & & & & \\
\hline Cluster A1 & 66.5 & 3.86 & .24 & .88 & 2.71 & 2.84 \\
\hline Cluster A2 & 33.5 & 7.09 & .40 & 1.23 & 3.37 & 2.96 \\
\hline 3-clusters & & & & & & \\
\hline Cluster B1 & 37.3 & 3.07 & .10 & .31 & 2.08 & 1.79 \\
\hline Cluster B2 & 29.2 & 5.02 & .44 & 1.72 & 3.65 & 4.36 \\
\hline Cluster B3 & 33.5 & 7.09 & .40 & 1.23 & 3.37 & 2.96 \\
\hline 4-clusters & & & & & & \\
\hline Cluster C1 & 37.3 & 3.07 & .10 & .31 & 2.08 & 1.79 \\
\hline Cluster C2 & 29.2 & 5.02 & .44 & 1.72 & 3.65 & 4.36 \\
\hline Cluster C3 & 14.9 & 6.28 & .26 & .67 & 2.84 & 1.77 \\
\hline Cluster C4 & 18.6 & 7.79 & .53 & 1.71 & 3.84 & 4.46 \\
\hline 5-clusters & & & & & & \\
\hline Cluster D1 & 37.3 & 3.07 & .10 & .31 & 2.08 & 1.79 \\
\hline Cluster D2 & 28.2 & 5.10 & .44 & 1.67 & 3.61 & 4.34 \\
\hline Cluster D3 & 1.0 & 2.75 & .50 & 3.25 & 4.58 & 4.75 \\
\hline Cluster D4 & 14.9 & 6.28 & .26 & .67 & 2.84 & 1.77 \\
\hline Cluster D5 & 18.6 & 7.79 & .53 & 1.71 & 3.84 & 4.46 \\
\hline Cell entres & ext & & & \\
\hline
\end{tabular}

Cell entries, except where specified, are mean scores within the relevant cluster. Total $\mathrm{N}=1266$; weighted by w8 


\section{Annex 4: Question Wordings for Component Authoritarian Populism Measures}

Ideological sympathy for market and rolling back of the state. Respondent's selfplacement on 0-10 Left-Right scale. The measure is an average of the self-placements made by each respondent across waves 1,2 and 4 of the survey. Other components all measured at Wave 10.

Britain Strong and Tough Foreign Policy. Question: From the list of foreign policy priorities, please select the one you think the United Kingdom should pursue in the $21^{\text {st }}$ Century (figures in parentheses indicate the percentage of respondents choosing each category): Helping the rest of the world by providing foreign aid and protecting human rights $(12 \%)$; Solving international problems by working with other nations and working through international organizations (44\%); Protecting British interests by being strong and tough with other nations and maintaining a powerful military (33\%); Avoiding involvement with other nations by simply minding our own business in international affairs (12\%). The measure used is a dummy where $1=$ chose the 'strong and tough' option, $0=$ not.

Negative Emotional Response to Immigration. Question: Please indicate which of the following emotions you feel towards immigrants: Angry, Happy, Disgusted, Hopeful, Uneasy, Confident, Afraid, and Proud. The measure is the sum of negative emotions (angry, disgusted, uneasy, afraid) specified by the respondent.

Critical of Human Rights. Statement: People who talk about protecting human rights are mainly interested in protecting the rights of criminals, not those of their victims. Strongly agree (19\%); Agree (26\%); Neither agree nor disagree (22\%); Disagree (16\%); Strongly disagree $(11 \%)$.

Disapproval of European Union. Question: Overall do you strongly approve, approve, disapprove or strongly disapprove of the European Union? Strongly approve (13\%); Approve (32\%); Neither/Don't Know (15\%); Disapprove (22\%); Strongly disapprove (19\%). 


\section{Endnotes}

\footnotetext{
${ }^{1}$ As Annex 1 shows, if we look at long-term opinion poll evidence, support for the governing party fell gradually but consistently from the late 1940s through to 2016, regardless of which party was in power. A simple trend function suggests that governing parties in the 2010s were on average 15 percentage points less popular that their counterparts in the late 1940s and early 1950 s.

${ }^{2}$ The Effective Number of Parties is defined as $\mathrm{N}=1 / \Sigma\left(\mathrm{Pi}^{2}\right)$ where $\mathrm{P}_{\mathrm{i}}$ is the proportion of seats (or votes) obtained by each party in the parliament.

${ }^{3}$ There are other more technical ways of calculating disproportionality. A common method is the Gallaher (1991) Index which takes into account the differences between each vote share and its seat share. On this measure, disproportionality at Westminster stood at 15.0 in 2015, compared with a European average of 6.5 for the period 2011-2015.

${ }^{4}$ The raw data are presented in Annex 2.

${ }^{5}$ Table A2 in Annex 2 takes the issue of causal direction a little further by regressing vote fragmentation on lagged values of PID and Class-Vote; and vice versa. The results are consistent with the conclusion that PID and Class-Vote are not endogenous to fragmentation.
} 